\title{
TRUST INVESTMENT CLAUSES: A PROBLEM FOR DRAFTSMEN
}

\author{
"Every testator, by the law of the land, \\ is at liberty to adopt his own nonsense \\ in disposing of his property." \\ -Vice-Chancellor Shadwell, quoted in Boulle \\ v. Tompkins, 5 Redf. 472,478 (N. Y. 1882).
}

When a man sits down with his lawyer to set up a trust, probably no decision which the two will have to make is more important than that of how the trustee is to invest the funds put in his care. And in no other part of the trust instrument can nonsense, if permitted to enter, produce more trouble for the trustee and the beneficiaries.

The investment clause of the will or the deed of trust really presents two problems: the donor, or perhaps the lawyer, must decide what kind of investments the trustee may make, and the lawyer must draft language for the trust instrument which will accomplish the desired result.

The donor must be quite careful in making his decision because the law says that his directions are to be followed literally, regardless of whether they are wise or for the best interests of the beneficiaries. ${ }^{1}$ If the donor chooses too conservative an investment policy, the life tenants may get too small an income; equally, an overly liberal investment policy will jeopardize the safety of the principal which is to go to the remaindermen.

The lawyer must be even more careful in drafting the investment clause, since an error on his part will not only hurt the beneficiaries, but may cost the trustee money. If the language is ambiguous and the trustee makes investments which a court later finds not to have been authorized by its reading of the instrument, the trustee is likely to have to make up to the beneficiaries any losses suffered on the unauthorized investments. ${ }^{2}$ This

1. 3 Bogert, The Law of Trusts and Trustees $\$ 681$ (1946); 2 Scott, The Law of Trusts $\$ 227.14$ (1939) (cited hereafter as BogerT and Scort respectively). "It is fundamental law that a testator or the creator of a trust has unlimited authority to direct how his money may be invested by his trustees, or may leave the matter of stch investment completely in the discretion of such trustees." Matter of Reid, 170 App. Div. 631, 634,156 N. Y. Supp. 500, 502 (1st Dep't 1915). The intention of the donor is to be followed even where he has directed speculative and hazardous investments. Greenhouse's Trust Estate, $338 \mathrm{~Pa}$. 144, 12 A.2d 96 (1940). Contra: Gould v. Gould, 126 Misc. 54, 213 N. Y. Supp. 286 (Sup. Ct. 1925), where the will gave the trustee power to invest in non-legals and specifically said that the trustee should not be liable for any resulting loss. The court permitted the trustee to be surcharged for the purchase of certain stocls, saying: "But authorizing a trustee to make such investments as he may think proper does not confer an unlimited power in the use of the trust property. . . . Although the will did not confine the trustees to so-called legal investments ... [they] were not atthorizcd to conduct a business or to finance railroads or to speculate in future values of railroads." Id. at $62,213 \mathrm{~N}$. Y. Supp. at 294-5.

2. 3 Bogert $\$ 708$; Moore, A Rationalization of Trust Surcharge Cases, 96 U. or 
possibility tends to make the trustee very conservative in interpreting the investment clause; even though the clause may have seemed clear to the lawyer who drafted it, the beneficiaries will not benefit from such liberal provisions as it may contain if the wary trustee finds any ambiguity in the language. And the trustee may well be right, since a carelessly drawn instrument can create an investment power far different from that originally intended.

\section{Choosing the Investment Power}

Three general possibilities lie before the donor in defining the magnitude of his trustee's investment power. He may restrict the trustee to ultraconservative investments; these he may enumerate himself or he may, in many states, restrict investment to a "legal list"- a collection, usually defined by statute, of the bluest chips, promising small but steady income and bedrock stability. ${ }^{3}$ Or he may select a number of specific investments or types of investments among which his trustee may choose. Finally, he may give the trustee "full power" to make his own selections. Although the limits of a full power are not precisely defined, the term seems usually to permit the trustee to purchase, after careful investigation, almost any security that is well-seasoned and non-speculative. ${ }^{4}$

Although the special circumstances of the donor, the size of the fund, the beneficiaries, etc., will of course dictate the choice made, in most cases the donor will find that a grant of full power to the trustee is best for the bene-

PA. L. REv. 647 (1948); Comment, Legal Lists in Trist Inzestment, 49 YALE L. J. $\$ 91$ (1940).

3. An excellent and well annotated Comment, 49 YALE L. J. $\$ 91$ (1940), is the best of the wealth of articles on legal lists. Much discussion has talien place in the periodicals attempting to distinguish between "mandatory" and "permissive" statutes. In theory the trustee who invests under a mandatory statute is required to stay within the list and must invest prudently even within those limits. Where a permissive statute governs, the trustee is protected if he invests within the list and may make other investments outside the list if he can show that he acted prudently. The distinction seems actually to be nonexistent in practice, since the trustee who stays within a mandatory list is almost never surcharged, while the trustee who goes beyond the list in a state with a permissive statute has very little chance of convincing a court that he acted with sufficient prudence to awoid surcharge. The risk involved is so great that few trustees ever dare to invest outside the legal list even where the statute is only "permissive."

In the following list of states with legal list statutes, the states where the statute is thought to be permissive rather than mandatory are italicized: Alabana, Arizona, Arlas:sas, Colorado, District of Columbia, Florida, Georgia, Idaho, Indiana, Iowa, Kansas, Louisiana, Maryland, Montana, Nebraska, Nwi Jerscy, New Hampshire, New Mexico, New York, North Carolina, North Dakota, Ohio, Oklahona, Pcnssylzinia, South Carolina, South Dakota, Temnessee, Utah, Virginia, West Virginia, Wisconsin, and Wyoming. 8 P-H TRUST SERV. II 15,301 (1948). Mississippi has no statutory list, but it is said that chancellors are assisted in deciding what are proper investments by the statutes with respect to the investment of sinking funds of tax districts. 3 BOGERI $\$ 638$.

4. 3 BOGERT $\$ 682 ; 2$ ScoTr $\$ 227.14$. Should the settlor desire to authorize more hazardous undertakings his task is not easy. See discussion, note 31 infro. 
ficiaries, best for the trustee, and best for the economy. The most obvious advantage of such a grant is that it should result in more income for the life tenant, who usually is the donor's wife or child. Most donors who consider the matter are willing to risk possible shrinkage in the amount which will go to the distant connections named remaindermen in order to assure an adequate income for the immediate dependents who are life tenants.

Both the life tenant and the remaindermen benefit from the growth factor inherent in the equity securities permitted only in full power portfolios. Common stocks have proven over the years to be an excellent hedge against inflation. Even when-as now-the prices of stocks fail fully to reflect a boom, the increased dividends which stocks pay in times of prosperity make the high cost of living less onerous to life tenants.

It cannot be denied that there may be an element of risk in the purchase of non-legals, but even the legal list securities are far from being absolutely safe. Municipalities do default on their bonds. The woe caused many trusts which held mortgages on real estate during the depression has left trust company files bulging with requests from beneficiaries to refrain from taking such mortgages, even though they are highly favored by legal lists. The melancholy experience of railroad securities is well known. Many trusts which were invested in non-legals certainly underwent similar misfortune, but these trusts had at least the solace of having received a more ample income in normal times. Moreover, the trustee without power to take remedial action on a broad scale found himself limited to expressions of commiseration. This inflexibility objection applies also to the establishment of a special investment power. The comparative safety of variouts types of investments changes with the years, and a donor who relies on his own judgment will leave his trustee powerless when that judgment becomes outmoded. ${ }^{6}$

In addition to the benefits it presents to the trust itself, a grant of full

5. Stone, Life Tenant vs. Remainderman, 84 TRusts \& Estates 530 (1947). Stone suggests that, since the life tenants are usually the primary objects of the donor's affection, all legal rules of construction should be resolved in favor of life tenants, and trustecs should depart from their usual conservative investment policies in order to obtain a larger income for the life tenant. In the course of a very muddy opinion, one court claims to have found indications in the case law that investment powers will in fact be interpreted more liberally where the beneficiaries include the widow or children of the testator. Matter of Hess, 171 Misc. 690, 13 N. Y. S.2d 701 (Surr. Ct. 1939).

6. "Who should know better than he how to invest and dispose of his moncy after his death? The only answer is: Time marches on. Thoughtless, playful children grow into serious-minded resourceful adults. Healthy, prosperous adults suffer illness, failure and the other casualties of life. The gilt-edge bonds of today are the cats-and-dogs of tomorrow. To regulate events in 1960 the judgment of a mediocre mind on the spot is incomparably preferable to the guess in 1940 of the greatest man who ever lived." LENCIr, Cases and Materials on Future Interests 240 (2d ed. 1940). See also Alton, Silgyestions for Drafting Trusts, 83 TRUSTs \& Estates 392, 393 (1946), reprinted as Some Practical Remarks About Trust Clauses, 26 ORE. L. REv. 39, 45 (1946). 
power to the trustee is desirable because it permits the funds of the trust to play a necessary role in the nation's economy. The greatest economic need in this country at the present time is for risk capital..$^{7}$ More than thirty-six billions of dollars are today held in trust, ${ }^{8}$ to a large extent unavailable as a possible source of such capital; prospective testators and settlors can perform a real public service by not further contributing to this process of financial inbreeding. And the notion that trust investment power has direct economic effects is not new. ${ }^{3}$ The common law originally sanctioned government consols as almost the only proper investment for a fiduciary largely because of the government's need for great quantities of borrowed capital. ${ }^{10}$

Finally, substantial trust investment in equity securities might very well redound to the benefit of more conservative holdings, for it is at least arguable that the vast sums of trust money which bid for the restricted classes of securities authorized by law are a major cause of the low return on legals.

A discretionary investment power offers such great advantages to the donor concerned with the welfare of his beneficiaries and of the economy that it is not surprising to find that an increasingly large number of trust instruments contain a clause giving the trustee full power over investments. ${ }^{11}$

7. Econoxic Reports of the President Part I, cc. 1, 4 (1948). The ceonomic effects of trust investments are analogous to those of investment by life insurance companies, just as the restrictions on trust investment are motivated by considerations similar to those which impel regulation of insurance companies. The economic problems presented by insurance company investment have been exhaustively analyzed in a Comment, Stattiory Regulation of Life Insurance Investment, 57 Y ALE L. J. 1256 (1948).

8. Stephenson, Trust Business in the United States 194\%, 27 Trust Bund 19 (1948).

9. A grant of full power makes it unnecessary for a court to have to stretch so iar to reach an economically desirable result as the courts did in Matter of London, 104 Misise. 372, 171 N. Y. Supp. 981 (Surr. Ct. 1918). The investment elause there required that the trust be invested in railroad bonds paying at least four percent. The trustee was surcharged for losses sustained on the purchase of some New York City bonds, but the court, in a fine patriotic fervor, refused to surcharge for losses incurred on Liberty Loan Bonds. The Surrogate argued that the testator could not have foreseen the government's need of money with which to wage a war, and said: ". . . I feel that were he alive he would have invested in these bonds." Id. at 377, $171 \mathrm{~N}$. Y. Supp. at 984. Although the result reached seems eminently desirable, the decision has been disapproved by a number of legal commentators. The Haryard LAw REYIEW says that the Surrogate sanetioned the patriotic motives of the trustees at the expense of the beneficiaries, $32 \mathrm{HAns}$. L. REv. 181 (1918), while Professor Scott calls the decision "a case which goes to the verge or beyond" and says that "it is doubtful whether most courts would feel that the circumstances would justify them in permitting such deviation." 2 Scorr \$227.14.

10. Comment, 49 Y ALE L. J. $\$ 91, \$ 92$ n. S (1940); cf. Mlatter of London, sistra note 9.

11. "The records of Fidelity-Philadelphia Trust Company of Philadelphiz show approximately $80 \%$ of the trust instruments accepted by them in the last ten years contain full power investment clauses. Of the remaining $20 \% 0$ about half contain special investment provisions, and half restrict the Trustee to legal investments. . . . In the past twenty-five or thirty years the trend has been toward liberalizing the powers of investment of the 


\section{Drafting the Investment Clause}

The substantive scope of the trustee's investment discretion determined, the problem of implementing the decision faces the draftsman squarely. The difficulties vary with the objective sought.

\section{Conservative Investment Power}

In states having a legal list of investments for trustees, the donor who wishes to limit his trustee to highly conservative holdings need but remain silent. Having grown up in the days when only government bonds and real securities were thought to be safe enough for a man investing another man's money, the law does its best to confine trustees to the limits of the legal list. ${ }^{12}$ Not only will the silent donor be supposed to have intended investment only in legals, but the donor who fails to express his wish for a broader power with the utmost clearness will have his trustee similarly limited. The benefit of any doubt which exists will always be given in favor of the legal list as against full power. ${ }^{13}$ Many states, however, have no legal list. There, the donor who remains silent will confer upon his trustee the broad discretion of a "prudent man" managing his own property.14 In "prudent man" states, therefore, the donor who wishes to confine his trustee more narrowly must enumerate the permissible investments. Since this task is similar to that of the donor in a legal list state who wishes to create a special investment power for his trustee, it will be covered by discussion of the latter.

Trustee. Whether this is the result of a better understanding of the investment problems 'of fiduciaries by the Bar, or by the creators of the trusts, I can not say-perhaps it is at combination of both." Communication to the YALE LAW Journal from E. W. Bainbridge, Trust Officer, Fidelity-Philadelphia Trust Company, December 20, 1948.

See also Riddre, The Investment Policy of Trust Institutions 284 (1934); Morris, Problems in the Drafting and Administration of Trusts, 26 Marq. L. REv. 57, 61 (1942). For a cynical and rather disapproving view of the same tendency, see Comment, Legal Lists in Trust Investment, 49 YALE L. J. 891, 907 (1940).

12. Restatement, Trusts $\$ 227 \mathrm{~b}(1935) ; 2$ Scott $\$ 227.12$.

13. See note 33 infra.

14. The leading case establishing the "prudent man" rule is Harvard College v. Amory, 9 Pick. 446 (Mass. 1830), where the court said, at 461: "All that can be required of a trustee to invest, is, that he shall conduct himself faithfully and exercise a sound discretion. He is to observe how men of prudence, discretion and intelligence manage their own affairs, not in regard to speculation, but in regard to the permanent disposition of their funds, considering the probable income, as well as the probable safety of the capital to be invested." Cf. King v. Talbot, 40 N. Y. 76 (1869). The "prudent man" rulc is in effect in California, Connecticut, Delaware, Illinois, Kentucky, Maine, Massachusetts, Michigan, Minnesota, Missouri, Nevada, Oregon, Rhode Island, Texas, Vermont, and Washington. 8 P-H TRUST SERv. $\llbracket 15,301$ (1948).

There is a tremendous literature discussing the rule. Possibly the best article is Shattuck, The Massachusetts Prudent Man in Trust Iwvestments, 25 B. U. L. Rev, 307 (1945). Moore, supra note 2, presents a brilliant analysis of the factors governing judicial response to particular investments. The analysis is applicable to states with legal lists as well as to "prudent man" states. 
There is a substantial danger in saying anything at all where legals are desired, ${ }^{15}$ as is illustrated by recent changes in the Fiduciary Act of Pennsylvania. ${ }^{16}$ For years the Act had permitted the usual assortment of high grade bonds and mortgages. During that period many a donor empowered his trustee to purchase "legal interest-bearing securities." In 1947 the legislature amended the legal list to include certain preferred stocks." ${ }^{17}$ Pennsylvania decisions indicate that preferred stocks can probably not be regarded as "interest-bearing." Is Therefore trusts using the language quoted must now be regarded as permitting an even narrower class of investments than that which the legislature regards as safe for fiduciaries.

There is a good possibility that the Pennsylvania court may be influenced by the legislative action sufficiently to hold that "legal interest-bearing securities" includes any security on the legal list. Rationalizations are available to justify such a result. ${ }^{13}$ But until the court does so rule, it would

15. Recent New York decisions highlight a few of the problems which can arise when investment clauses speak of legal securities. In In re Hoyt's Estate, 294 N. Y. 373, 62 N. E.2d 609 (1945), 46 CoL. L. Rev. 154 (1946), 32 VA. L. REv. 426 (1946), the instrument directed investment ". . . only in such securities as savings banks under the Banling Laws of New York are expressly authorized to invest deposits." The applieable banlsing law at that time of testator's death allowed investment in mortgages but did not expressly authorize mortgage participations, and the court allowed the trustees to be surcharged for purchasing mortgage participations. Cf. MIatter of Putnam, 42 N. Y. S.2d 367 (Surr. Ct. 1943), where the donor said: "I . . . direct that my said trustees need not be limited to investments required for savings banks." The court found a few trivial instances in which the legal limits of investment for trustees were broader than for savings banks, and held that the language did not authorize purchase of securities not legal for trustees. Compare President \& Directors v. Erlandsen, 36 N. Y. S.2d 136 (Sup. Ct. 1942), aff'd per curiam, 266 App. Div. 8\$3, 43 N. Y. S.2d 639 (2d Dep't 1943) (non-guaranteed mortgage certificate on legal list held improper investment where instrument authorized ". . guaranteed first mortgages, guaranteed first mortgage certificates, or in such other securities as may be legal for the investment of trust funds"), arith In re MicIntyre's Estate, 249 App. Div. 833, 292 N. Y. Supp. 746 (2d Dep't 1937), aff'd fer curian, 275 N. Y. 603, 11 N. E.2d 776 (1937) (non-guaranteed mortgage on legal list held proper investment where will authorized "... those investments prescribed by law for trustees and no other save bonds or mortgages fully guaranteed").

16. PA. Stat. Awn., tit. 20, $\$ \$ 01$ (Purdon, Supp. 1948).

17. Id. at $\$ 801-16$. In order to be eligible, preferred stocks must be listed on the New York Stock Exchange, must have been approved by any appropriate state or federal regulatory bodies supervising the issuing corporation, and must be shares in a corporation which in the past ten years has never defaulted in the payment of preferred dividends and which has earned a net profit after all interest, expenses, and tases, in at least cight of those years.

18. See notes 45 and 47 infra.

19. In Craven's Estate, $25 \mathrm{~Pa}$. D. \& C. 289 (1935), the will authorized investment in "... bonds secured by mortgages, or loans of the United States of America, State of Pennsylvania or City of Philadelphia." There was no language to indicate any further power to invest in such other securities as might be legal. The Orphan's Court claimed to find that the class of securities permitted by the instrument was coextensive with the class of securities authorized as legal investments at the time the will was drawn. It held, 
be a brave trustee indeed who would take advantage of the modernization of the legal list to purchase preferred stock for such a trust.

\section{Special Investment Power}

The most difficult problems in draftsmanship are caused by those donors who wish to give their trustee an investment power different from both full power and the legal list. They must construct an entire investment standard of their own, a task which has taken the law many statutes and much litigation to accomplish. Even if the donor is successful, his effort is probably ill-advised, since the trustee can usually formulate a sounder investment policy at the time of investment than can the donor years in advance. And such directions add to the difficulties and expense of administering the trust.

But if the donor is persistent in his desire for a special investment power, the easiest and safest method of setting out the new investment standard is to take the standard of legal list or full power as a frame of reference, and then prescribe such additions to or subtractions from this standard as seem desirable to the donor. Very few problems will arise if the direction is to invest in "railroad stocks and such securities as may be legal for trustees," ${ }^{20}$ or if

therefore, that by the language quoted the testator was saying in effect that the trustec might invest in legal securities, and that he merely chose to define such an investment power by specification, rather than by using the shorthand phrase, "legal investments." The trustee in this case had purchased mortgage participation certificates, a form of security which did not become a legal investment until some years after the testator's death, but having interpreted the will as giving a legal power of investment, the court refused to hold the trustee liable.

An analogy can be erected between Craven's Estate and trusts which speak of "Iegal interest-bearing securities" or indicate the same thing by equivalent language. When instruments drawn prior to 1947 used such a phrase, they were describing a class coextensive with legals generally. Under the Craven rule, the trustee under such an instrument is still cloaked with a full legal power, even though the legislature has scen fit to permit certain restricted investments in securities which are not, strictly speaking, "interest-bearing."

Of course Craven's Estate is only a lower court decision, and its authority is further weakened by the almost desperate over-ingenuity which the court was forced to cmploy to reach its result. Some support for such an argument as that outlined can be found in another 1947 amendment to the Fiduciaries Act, which specified that ". . . the terms 'legal investment' or 'authorized investment' or words of similar import as uscd in . . . [tise trust instrument] ... shall be taken to mean any investment permitted under the terms of . . . [the legal list]." Pa. Stat. ANn., tit. 20, $\$ 801-17 \mathrm{~b}$ (Purdon, Supp. 1948). Such arguments may prove convincing to any court too timid to face up to the fact that "legal interest-bearing securities" and similar phrases are legal clichés tossed in to impress donors who obviously had no desire to limit their trustee any more severely than the legislature limited him. See Haggerty, Some Aspects of the Obligations of Ncw Yorl: Fiduciaries With Respect to the Making and Retention of Investments, 16 Ford. L. Rev. 1, 153 (1947), who says, at 9: "It should be realized that very often, the words used or the phrases employed should not be analyzed literally, because they are legal 'clichés' if not idioms, and hence meaningless if considered by themselves."

20. Cf. In re Harbeck's Estate, 142 Misc. 57, 254 N. Y. Supp. 312 (Surr. Ct. 1931). 
the trustee is authorized "to make any kind of investment, whether or not legal, except mortgages on real estate." 21

It is when the donor attempts to specify all the types of permissible investments-as he must, in a "prudent man" state where he wishes conservative investments - that really grave dangers are likely to be encountered. Where the instrument permits purchase of "mortgages," are mortgage participations proper investments?"2 Will the trustce be surcharged who purchases municipal bonds or school district bonds when the will mentioned only "state and government bonds"?23 Is a debenture a "bond or obligation?" "2 As the examples indicate, no matter how specific the language used, it is rare that every possible kind of investment is considered and either banned or definitely permitted. ${ }^{25}$

Another problem which recurs frequently when donors attempt to set up a special investment power is whether mention of a particular type or types

But cf. Matter of Hepburn, N. Y. L. J., Oct. 23, 1934, p. 1407, cols. 5, 6 (Surr. Ct.), where a direction to invest in ". . . government bonds or securities of like character" was held to mean United States Bonds, state bonds, or "good" municipals, but not to include legals generally.

21. But cf. Jones v. First Minneapolis Trust Co., 202 Mfinn. 187, 277 N. W. 899 (1938), 22 MrN. L. REv. 1070, in which it was held that a grant of power to invest in "... first mortgages or improved real estate, in municipal or corporation bonds or in any other form of income bearing property, except real estate..." did not grant authority to invest in corporate stock. The court refused to reverse its construction of that will even after the adoption by Minnesota of a "prudent man" statute which specifically authorized investment in stocks. In re Jones' Will, 221 Minn. 524, 22 N. W.2d 633 (1946).

22. Yes: Paul's Estate, $338 \mathrm{~Pa} .191,12$ A.2d 565 (1940) ; Dillon's Estate, 324 Pa. 252, 188 Atl. 134 (1936); D'Happart's Estate, 132 Pa. Super. 326, 200 Atl. 927 (1938); Craven's Estate, 25 Pa. D. \& C. 289 (1935). No: In rc Shaw's Estate, 122 N. J. Eq. 536, 195 Atl. 525 (1937); In re Haydock's Estate, 158 Afisc. 404, 284 N. Y. Supp. 931 (Surr. Ct. 1935) ; Matter of Waxelbaum, 156 Misc. 45, 281 N. Y. Supp. 186 (Surr. Ct. 1935); In re Mendel's Will, 164 Wis. 136, 159 N. W. S06 (1916); 3 Bocers \$683. Afaybc: Nossaxian, Trust Adarnistration and Taxatzon $\$ 459$ (1945).

23. Yes: Matter of Stillman, 53 N. Y. S.2d 718 (Surr. Ct. 1945). Just as a trustee directed to purchase bonds of any "British colony or dependency" may not purchase bonds of a province of Canada. In re Sir S. M. Maryon-Wilson's Estate, [1912] 1 Ch. 55. But cf. Colonial Trust Co. v. Brown, 105 Conn. 261, 135 Atl 555 (1926).

24. Probably. Although it is conceivable that ciusdem gencris might be applied to limit the meaning of "obligations" to such as are, like bonds, secured, it is more likely that the use of the extra word, "obligations," would be held to mean that something in addition to bonds was intended. But cf. In re Willis, [1911] $2 \mathrm{Ch}$. 563, where the power to invest in "preference stock" was held not to include the power to purchase "preference shares," a type investment which is technically very slightly different.

25. The danger of trying to be too specific is seen in investment clauses of the type which say: "Mfy trustee may invest in such mortgeges, corporation bonds or stods as it may deem advisable, it being my wish that my trustee shall not be confined to legal investments." A literal reading of the language would preclude investment in government bonds, ground rents, or debentures, although clearly the testatrix wished to give a full power. 
of investment operates to prevent investment in legals generally. ${ }^{20}$ Where the will announces firmly "I direct my trustee to invest in preferred stocks" or "my trustee shall invest in preferred stocks," it is probable that a court will hold that preferred stocks only are to be purchased. ${ }^{27}$ But if the will or deed of trust says instead "I authorize my trustee to invest in preferred stocks," or "my trustee may invest in preferred stocks," it is more likely that a court will hold that preferred stocks may be bought along with any legal list securities. ${ }^{28}$ Careful draftsmanship can readily avoid this emphasis placed upon a distinction of words. "Preferred stocks only" would accomplish one result, while "preferred stocks and legal securities" would protect the trustee in the broader investment policy.

A variant on the same problem is presented by the trust instrument which says: "To invest . . . at discretion, without confining my Trustee to what are known as Legal Investments. I specifically confer upon my Trustee the right to invest in preferred stocks." The first sentence gives a full power and the second sentence is purely permissive. Yet the rule expressio tinitls est exclusio alterius seems to require that preferred stocks be the only non-legal investments in this trust. If the testator had desired investment in nonlegals generally, his mention of preferred stocks is unnecessary and meaningless.

Somewhat similar to the investment clause which attempts to set up a special standard for investments is the clause which sets out either a legal or a full power but then goes on to express a preference of the testator for certain types of investment. Such language is litigated very infrequently, but it puts the trustee in an embarrassing position. Suppose the founder

26. E.g., compare In re Shafer's Will, 69 N.Y.S.2d 446 (Surr. Ct. 1947), with President \& Directors v. Erlandsen, 36 N. Y. S.2d 136 (Sup. Ct. 1942), af'd per curian 266 App. Div. 883, 43 N. Y. S.2d 639 (2d Dep't 1943). "If the statute fixing the legal list states that a trustee may invest in any of the securities named, unless expressly prohibited by the settlor, a direction by the settlor to invest in a named security does not exclude the power to invest in the listed investments. An implied prohibition is not enough. But where there is no such statutory demand for an express prohibition of the legal list, a direction by the settlor to invest in government bonds, or real estate mortgages, or any other specific security, naturally impliedly excludes a power to invest in any other securities, whether mentioned on the legal list or not." 3 BoGEst $\$ 683$.

27. Cf. In re Shaw's Estate, 122 N. J. Eq. 536, 195 Atl. 525 (Ch. 1937) ; Matter of Irwin's Estate, 59 Misc. 143, 112 N. Y. Supp. 205 (Surr. Ct. 1908); In re Mendel's Will, 164 Wis. 136, 159 N. W. 806 (1916). In Nola's Estate, 333 Pa. 106, 3 A.2d 326 (1939), where the instrument said: "I order and direct... (that real estate be converted) ...," the court said that the words used were "... as clear, as unambiguous, and as imperative as any words in the English language could be," $i d$. at 108, 3 A.2d at 328 , and held that the trustee was not permitted to use his discretion as to the wisclom of sale.

28. E.g., In re Channing's Estate, 129 Misc. 393, 222 N.Y. Supp. 351 (Surr. Ct. 1927); In re Warren, [1939] Ch. 684; see In re Hamersley's Estate, 152 Misc. 903, 909, 274 N.Y. Supp. 303, 310 (Surr. Ct. 1934) ; Falls v. Carruthers, 20 Tenn. App. 681, 690, 103 S.W.2d 605, 611 (1936). But cf. In re Bruen's Estate, 83 N. Y. S.2d 197 (Surr. Ct. 1948). 
of See Right Spectacles Co. gives his trustee full power but adds: "I hope that a large part of this trust is invested in stock of the See Right Spectacles Co." Years after the donor's death the future of See Right loolss so cloudy that the trustee sells the stock of the company he is holding, and invests in other securities. If the trustee is wrong, and See Right continues prosperous while the new securities decline in value, it will be difficult to explain in a surcharge action why the donor's wish was disregarded.9 And yet the precatory language of the investment clause is little protection to the trustee if he continues to hold the See Right shares against his better judgment and the shares become worthless. is

Another familiar type of precatory language is: "It is my wish that the trustee shall consider safety of principal rather than a high rate of return when making investments." This language is almost meaningless. Trustees strive to keep a balance between the life tenant and the remaindermen, but principal emphasis is always placed on preserving intact the corpus of the trust. $^{31}$ The donor who really wishes a greater degree of safety than is usual

29. "Testators in making disposition of property frequently use the word 'desire' as the equivalent of 'direct' and such is its ordinary interpretation in the law of wills." In rc Gardner's Estate, 89 Colo. 523, 52S, 4 P.2d 686, 68S (1931). Accord: In re Rolston's Estate, 162 MIisc. 194, 294 N. Y. Supp. 112 (Surr. Ct. 1937); cf. In re Olcott's Will, 163 Misc. 890, 293 N. Y. Supp. 267 (Surr. Ct. 1937) (words of testator that it was his "wish" that trustees not make any investment to which beneficiaries should object held, in light of rest of will, to be mandatory).

30. Where the donor spoke of his "intention and preference" for a particular course of action by his fiduciaries, his language was held to be precatory, not creating more than a certain moral obligation on the part of the executors. Ist re Stulman's Will, 146 Misc. 861, 263 N. Y. Supp. 197 (Surr. Ct. 1933). Accord: Colonial Trust Co. v. Brown, 105 Conn. 261, 135 Atl. 555 (1926) ("It is my wish . . . my request . . ."); Irs re Bud:ley's Will, 135 Mlisc. 156, 237 N. Y. Supp. 293 (Surr. Ct. 1929) ("I also wish ... ."); In re Scott's Will, 204 N. Y. Supp. 478 (Surr. Ct. 1924) ("... it is my desire . . ."); Lindsay's Estate, $211 \mathrm{~Pa}$. 536, 166 Atl. 848 (1933) ("It is my wish .. ."). In Brown y. French, 125 Mass. 410 (1878), the investment clause told the trustees to "... use their own judgment as to investing the moneys arising from my estate; at the same time I would recommend to them the propriety of keeping at least one half of the same invested on mortgage of unencumbered real estate, as I think well of that lind of security." The court refused to hold the trustees liable for completely ignoring the testator's vish and holding no mortgages whatsoever.

31. In Falls v. Carruthers, 20 Tenn. App. 681, 103 S. W.2d 605 (1936), 15 TEx:3. L. REv. 169 (1938), the trustee was empowered “. . . to make such investments as he may see fit, looking always to the safety of the investment, rather than to a high rate of interest ..." The court called the last half of the clause "purely advisory or precatory;" id. at $691,103 \mathrm{~S}$. W.2d at 611, and held that the trustee had not exceeded his power in purchasing non-legals.

But see Holden, Estates Under Wills and Trust Agregsemts 37 (1923), who says of the type clause under discussion: "It is not necessary, for even without it the trust company would make safety of the principal a first consideration. But to malie this clear to the beneficiaries, and to sustain the trustee in its insistence upon safety as a first consideration, it is sometimes advisable to insert such a clause."

A donor who wished to have safety of principal ignored and a high income made the 
can easily limit his trustee to the ultrasound investments of the legal list, or even to government bonds only. Language such as that quoted is of no value as a guide to the trustee, but can embarrass him considerably if he suffers a loss on investments which hindsight may regard as having been speculative.

\section{Full Power}

Where the donor decides on a grant of full power, it should be the simplest of matters for his lawyer to implement that decision. In some states it is, for the trust instrument need but remain silent and the law will give the trustee substantially equivalent discretion-that of a prudent man managing his own investments. ${ }^{32}$ Where a legal list is in existence, the same objectives can be attained only by drafting a most forceful clause which makes it clear that there is to be no limit on the powers of the trustec. ${ }^{\text {ja }}$ Form books abound with clauses aimed at conferring the broadest of investment powers, ${ }^{34}$ and although many may be criticized as overly involved, ${ }^{35}$ they may be successful in establishing about as much discretion

sole criterion for investment would probably have difficulty in drafting an investment clause sufficiently explicit to overcome the inherent conservatism of the type persons and corporations that act as trustees. In particular, a corporate trustee would undoubtedly regard it as abominable public relations to have a trust completely wiped out by bad investments, even though the donor specifically directed a speculative and hazardous investment policy. Probably the only way to insure that a high return would be preferred to safety of principal is the unpalatable expedient of including in the investment clatse specific directions as to the precise class of investments to be chosen.

32. See note 14, sipra; note 36 infra.

33. Investment in non-legals "may be authorized by the creator of the trust, but where such a provision is relied on, it is for the trustee to establish it with the utmost clearness, and when shown it will be strictly construed. . . . The power ought not to be sustained upon conjecture, nor inferred from . . . express grant of discretion as to matters not relating to the management of the fund. The presumption is against the existence of such a power, and all doubts should be resolved against the party asserting it." Barker's Estate, 159 Pa. 518, 528-9, 28 Atl. 365, 367 (1894). Accord: Babbitt v. Fidelity Trust Co., 72 N. J. Eq. 745, 66 Atl. 1076 (Ch. 1907); Matter of Robbins, 135 Misc. 220, 237 N. Y. Supp. 409 (Surr. Ct. 1929); Taylor's Estate, 277 Pa. 518, 121 Atl. 310 (1923). Where alternative interpretations of the investment power are passible, courts will adopt the more conservative of the two. Equitable Trust Co. v. Snader, 20 Del. Ch. 278, 174 Atl. 132 (1934). A similar principle seems to guide trustees in states such as Texas, where the custom of the community is regarded as the most important limitation on trust investments, and where investments of a type not customary for trustees in that state will be made only if they are specifically authorized in the trust instrument. Kingr, I'ritst Investments in Texas, 21 TExAs L. Rev. 223 (1943).

34. See, e.g., the proposals made in Stephenson, Trust Investment Provisions Which Have Worked Well, 5 Law \& Contemr. Prob. 377 (1938).

35. Ibid. The following form, recommended by a leading trust company, is typical: "The investment of the principal or corpus of the estate hereby given in trust is left to the discretion of the Trustee, with the view of thereby obtaining a larger income therefrom than would be received were it invested solely in legal securities. The trtstee shall not be hampered by any laws or rules of law which now exist or may hereafter exist in 
as the trustee holds under the "prudent man" rules. "s But courts from state to state have constructed such a variety of traps that unwary scriveners are constantly finding that language which they had thought to be unambiguous could be interpreted to mean something other than full power.

One common investment clause which has caused difficulty to many trustees and courts is that which gives the trustee discretion over investments without specifically exempting him from the requirements of the legal list. The better recent decisions have taken the word "discretion" as a peg on which to hang full power for the trustee. ${ }^{57}$ This view is of such recent vintage in many jurisdictions that it is likely to be too strictly construed by the trustee; the same trust company which regards a direction to invest "at discretion" as granting full "power may continue to regard itself as confined to legals where the words of the instrument are "at pleasure." But most courts have recognized that such phrases as "as he deems best" and "as may be for the best interests of my estate" are synonyms for "at discretion." 38

regard to the character of investments to be made by trustees, but shall invest the principal or corpus in whatever manner it may see fit, using the same diseretion as in maling its own corporate investments, without being in any way responsible or liable for any losses or depreciation in value that may result therefrom." Though it would probably be suecessful in insulating the trustee from all responsibility-if indeed that is desirable-there is nothing really wrong with such a clause, except that it could have been said much more simply and easily.

36. Moore, supra note 2, says, at 657: "A power to invest in 'non-legals' . . probably gives the fiduciary even greater opportunity for exercise of discretion than the trustee has in a prudent man state" Moore's argument apparently would be that the trustee in a "prudent man" state has an affirmative duty of care and prudence, while the trustee investing under a grant of discretion in a legal list state is liable only in case of supine negligence or willful default. Although the limits of a discretionary power are admittedly rough, it seems probable that the distinction suggested is mainly on the rerbal level, and that results in similar factual situations involving the "prudent man" rule in one instance and a grant of discretion in the other would not be significantly different. Cf. Litarty Title \& Trust Co. v. Plews, 142 N. J. Eq. 493, 60 A.2d 630 (Ch. 1948). But ef. Afiller v. Pender, 93 N. H. 1, 34 A.2d 663 (1943).

37. Wilmington Trust Co. v. Worth, 19 Del. Ch. 314, 167 Atl. 848 (1933) (". . . to invest... from time to time in, what in the discretion of the trustces are, good investments"); Pennsylvania Company for Insurances on Lives and Granting Annuities v. Board of National Alissions of the Presbyterian Church, 139 N. J. Eq. 71, 50 A.21 393 (Ch. 1946) (“. . . discretion ..."); Duncklee v. Butler, 30 Mlisc. 58,62 N. Y. Supp. 921 (Sup. Ct. 1899) (“. . . at his own discretion") ; Carr's Estate, 355 Pa. 438, 50 A.2d 330 (1947) (". . . full power and authority in their discretion to invest . . .) ; 3 EçEesr $\S$ CS2; 2 Scort $\$ 227.14$.

In 1929 Washington provided by statute that a grant of discretion as to investment should carry a power to buy non-legals, WASE. KEv. StAT. \$3255p (Remington, 1932), but that provision was repealed and its content was not reenacted when substantial cinanges were made in the State Banking Law in 1941. Wase. Rev. Srst. \$3255-19 (Remington, Supp. 1941).

38. Title Guarantee Loan \& Trust Co. v. Woodward, 23S Ala. 304, 191 So. 363 (1939) (". . as it deems best. ..."), 1 AlA. Lavyer 65 (1940); City Bank Farmers Trust 
Such a broad view is, however, far from being universal. Moreover, the argument is still plausible that a grant of discretion without specific waiver of the legal list gives the trustee discretion to choose only among legals. ${ }^{33}$ And if the investment clause happens, as many do, to include the phrase "from time to time" in an authorization to invest as the trustee cleems best, it may be held that the discretion runs only to the time of investing, and not to the type of investments to be made. ${ }^{40}$ The effect of this kind of general grant of discretion may be limited, too, in places where statute or custom forbids investment in unusual kinds of securities-particularly stocksunless they are specifically named in the investment clause. ${ }^{41}$

Co. v. Lewis, 122 Conn. 384, 189 At1. 178 (1237) (". . . as they may consider safe. . . ."); Armstead v. Trust Co. of Georgia, $180 \mathrm{Ga} .148,177$ S. E. 787 (1935) (". . . complete authority to make investments according to its best judgment. ..."); Matter of Backits, 175 Misc. 13, 22 N. Y. S.2d 613 (Surr. Ct. 1940) (". . . as he may be advised. . . "); Guaranty Trust Co. of New York v. Leach, 168 Misc. 526, 5 N. Y. S.2d 628 (Sup. Ct. 1938) (". . . any other property, either real or personal, that it may think best"); Matter of Leavitt, 135 Misc. 387, 238 N. Y. Supp. 109 (Surr. Ct. 1929) (". . . as they may sclect as being reasonably safe. . .."); Matter of Leonard's Wiil, 118 Misc. 598, 193 N.Y. Supp. 916 (Surr. Ct. 1922) (". . . to keep the principal thereof invested so as to bring in the largest income compatible with reasonable safety of the principal. ..."); Willis $v$. Braucher, 79 Ohio St. 290, 87 N. E. 185 (1909) (". . . in such manner as she or they may think best. . . ."); Greenawalt's Estate, 343 Pa. 413, 21 A.2d 890 (1941) (". . . as may be for the best interests of my estate") ; Nossaman, Trust Administration AND TAXA. THON $\S 459$ (1945).

39. Cf. Michigan Home Missionary Society v. Corning, 164 Mich. 395,129 N. W. 686 (1911) (". . . their best skill and discretion. ...") ; Brown v. Brown, 72 N. J. Eq. 667,65 Atl. 739 (Ch. 1907) (". . . sound, productive securities, such as they may deem best. . .."); Matter of Hall, 164 N. Y. 196, 58 N. E. 11 (1900) (". . . any security, real or personal, which they may deem for the benefit of my estate. . . "); Matter of Carnell, 260 App. Div. 287, 21 N. Y. S.2d 376 (3d Dep't 1940), aff'd per cttriam 284 N. Y. 624, 29 N. E.2d 935 (1940) (". . . other securities purchased in tho excrcise of their good judgment and discretion. All such securities, however, . . . to be always well selected, and well secured securities, as distinguished from spectulative securities or investments") ; Pabst v. Goodrich, 133 Wis. 43, 113 N. W. 398 (1907) (". . . as they shall deem best. . . ."). See Stephenson, supra note 34, at 382 .

Analogously, the investment clause of a trust fund which was to be ". . . reinvested in their discretion ... in other real estate or securities" was interpreted as giving discretion only between realty and personalty, with no power to purchase non-legals, in Equitable Trust Co. v. Snader, 20 Del. Ch. 278, 184 Atl. 132 (1934). Where an investment clause directed investment in ". . . first class railroad bonds or stock or any other such sccurities as they in their best judgment shall deem proper," the court applied the principle of moscitur a sociis to hold that "other securities or property" extends only to legals. In $r e$ Harbeck's Estate, 142 Misc. 57, 254 N. Y. Supp. 312 (Surr. Ct. 1931).

On the other hand, it has been said that a grant of discretion would be a useless legal formality if it were interpreted to mean only discretion to choose from among legals. City Bank Farmers Trust Co. v. Lewis, 122 Conn. 384, 189 At1. 178 (1937).

40. Babbitt v. Fidelity Trust Co., 72 N. J. Eq. 745, 66 At1. 1076 (Ch. 1907) ; cf. In re Hazeldine [1918] 1 Ch. 433.

41. E.g., Sellers v. Milford, 101 Ind. App. 500, 198 N. E. 456 (1935), 12 IND. L. J. 80 (1936), where the trustee was surcharged for purchase of common stocks under an 
Even where the language would otherwise seem to create a full power, certain words tend to produce strong and confused reactions from courts. The word "securities" is one of these; technically a share of stock is not a "security," 42 and for years courts norried over whether a trustee had exceeded his authority in purchasing stocks where the investment clause mentioned "securities." In everyday parlance of both laymen and lawyers, a share of stock is certainly a "security," and almost all courts now recognize this. ${ }^{43}$

An even more troublesome word is "interest." Although it is not uncommon to speak of "interest" when what is really meant is "income" or perhaps "rate of return," 44 most courts will still hold that if a donor spealis of "interest-bearing securities" or of putting money "at interest," he means to prohibit his trustee from purchasing preferred or common stock. ${ }^{45}$ In construing "interest," the court may go beyond the words of the instrument themselves, and allow purchase of stock where it finds other evidence that the donor meant that stocks should be held-e.s., if he left much of his own

investment clause which directed the investment of the corpus so as to produce as much income as was safe and reasonable. See Stephenson, supra note 34, at 3\&2; King, stspra note 33 .

42. In re Mildeberger's Will, 212 App. Div. 727, 209 N. Y. Supp. 649 (1925).

43. "In common parlance, among all classes of people familiar with 'securities', banlers, brokers, investors, speculators and lawyers, the term is used as signifying all classes of investments." 1icGraw's Estate, $337 \mathrm{~Pa}$ 93, 95, 10 A.2d 377, 378 (1940). Accord: City Bank Farmers Trust Co. v. Lewis, 122 Conn. 3S4, 189 Atl. 178 (1937); Equitable Trust Co. v. Marshall, 25 Del. Ch. 23s, 17 A.2d 13 (1940); Fox v. Harris, 141 Sid. 495, 119 At1. 256 (1922); In re First National Bank \& Trust Co., 202 Mfinn. 206, 277 N. W. 909 (1938) ; Fairleigh v. Fidelity National Bank \& Trust Co., 335 M10. 360, 73 S. W.2d 248 (1934) ; Fidelity Union Trust Co. v. Lowy, 123 N. J. Eq. 90, 196 Atl. 369 (Ch. 1938); MIatter of Loose's Will, 167 Misc. 764, 4 N. Y. S.2d 611 (Surr. Ct. 1938); Wood's Estate, $130 \mathrm{~Pa}$. Super. 397, 197 Atl. 638 (1938), \&6 U. of PA. L. Kev. 791; Restate:arti, TRUSTs $\$ 227$, comment $u$ (1935) ; cf. Hanson v. First National Banl, $217 \mathrm{Alz}$ 426, 116 So. 127 (1928); Pennsylvania Company for Insurance on Lives and Granting Annuitics v. Board of National Missions of the Presbyterian Church, 139 N. J. Eq. 71, 50 A.2d 393 (Ch. 1946) ("investments" held to include stocks); MFatter of Hoaglund, 74 N. Y. S.2d 156 (Surr. Ct. 1947) ("securities" held to include shares of a common trust fund); sce Miller v. Pender, 93 N. H: 1, 4, 34 A.2d 663, 664 (1943).

But see 3 BOGERT $\$ 683$, which says: "An authorization to inrest in 'securities' excludes corporate stocks ..." And Nossanran, Trust Adsmistration and Tasirion $\S 459$ (1945), says that stocks may or may not be held to be a "security."

44. E.g., Smith v. Southern Foundry Co., $166 \mathrm{Ky} .20$, 179 S. W. 205 (1915), where a share of preferred stock provided that it was to bear "interest" at a certain rate.

45. 'While 'interest' may be used loosely to denote income, in its accurate sense it designates income derived from a debt or obligation." Berge's Estate, 30 Pa. D. \& C. 549, 558 (1937) (stocks not permitted where investment clause spoke of ". . safe securities at interest"); Williams v. Cobb, 219 Fed. 663 (2d Cir. 1914), aff'd 242 U. S. 307 (1916); Kinney v. Uglow, 163 Ore. 539, 9S P.2d 1006 (1940) (trustee surcharged for purchasing stocks, even with approval of court, where instrument spoke of ". . . some safe, interestbearing security, approved by the court"); Cope's Estate, 351 Pa. 514,41 A.2d 617 (1945), infra note $47 ; 3$ BOGERT $\$ 683$. 
estate in stocks. ${ }^{46}$ If the donor was a bank president who might be expected to have known the difference between "interest" and "income," the court will probably refuse to allow the purchase of stocks. ${ }^{47}$ And it is, of course, common, where "interest" is mentioned, to examine the remainder of the will for any indications it may give as to how the word was used by the donor. ${ }^{43}$ But while these factors may serve occasionally to prevent unintended results, it is more probable that the most forcefully worded grant of discretion to the trustee will be held not to authorize investment in stocks if "interest" is mentioned.

In some jurisdictions words such as "good" or "safe" or "sound" have an emotive tinge. In all probability a court would allow full power to a trustee told ". . . to invest in good sound securities without being confined to legals." "49 But if the investment clause should be weaker to the extent of saying only ". . . to invest in good sound securities as he may deem best," the judicial reaction to an argument that full power was granted might be different. The court would probably come to the aid of what it regards as the donor's best interests with such language as: ". . . it would be a shocking interpretation of his intention and his language to hold that he meant something less sound than what the law regards as sound." 50 The trustee would then be confined to legals. ${ }^{61}$ Another court in a somewhat similar case

46. E.g., Poor v. Hodge, 311 Mass. 312, 41 N. E.2d 21 (1942).

47. The testator's experience as a bank president seems to have influenced the court in Cope's Estate, $351 \mathrm{~Pa}$. 514, 518, 41 A.2d 617, 619 (1945), but the court makes the broad statement that: "No distortion of the language quoted can convert the word "interest' to 'income', nor can common stocks be considered 'interest paying'" Id. at 518, $41 \mathrm{~A} .2 \mathrm{~d}$ at 618. The investment clause read: "... to make investments in any interest paying securities they deem good and safe, without being restricted to . . . [legals]." The decision of the court is approved in a very thorough Note in 31 VA. L. REv. 922 (1945).

48. E.g., Gillingham's Estate, $353 \mathrm{~Pa}$. 493, 46 A.2d 269 (1946). The instrument in that case permitted investment ". . . in such securities as my said Executors and Trustecs ... may deem prudent, without restriction to so-called legal investments, my object being to secure, if possible, a rate of interest higher than can be obtained by investment in securities designated by law for the investment of Trust monies. ..." The court said that properly to interpret the investment power it was necessary to look to the four corners of the will, and since "income" and "dividends" were mentioned elsewhere in the instrument, the court decided that common stocks were a proper investment despite the mention of "interest."

49. The language quoted in the text is not uncommon in trust instruments. No case has been found in which it has been construed, but every decision on analogous language indicates that such a clause undoubtedly gives full power.

50. Hale's Estate, $347 \mathrm{~Pa} .177,178,32$ A.2d 20, 21 (1943).

51. E.g., Brown v. Brown, 72 N. J. Eq. 667, 65 Atl. 739 (Ch. 1907) (". . . sound, productive securities, such as they may deem best ..."); cf. Matter of Carnell, 260 App. Div. 287, 21 N. Y. S.2d 376 (3d Dep't 1940), aff'd per curiam 284 N. Y. 624, 29 N. E.2d 935 (1940) (". . . other securities purchased in the exercise of their good judgment and discretion. All such securities . . . to be always well selected, and well secured secturitics, as distinguished from speculative securities or investments"); Matter of Morris, 153 Misc. 905, 276 N. Y. Supp. 254 (Surr. Ct. 1934) (". . . in safe and stable interest bearing 
has declared that the legal list provided for absolute safety and that the testator probably only wanted reasonable or relative safety. ${ }^{52}$ The rationale arising from the facts in that case might well be applied more extensively.

Interesting metaphysical distinctions can be made when words such as "good" or "sound" are used. If they describe the type investment the trustee may make, he will, as has been seen, probably be confined to legals. But if the language should be ". . . to invest in such securities as in the judgment of the trustee are good and sound," it is reasonably sure that the trustee would be allowed to exercise full power. ${ }^{13}$ Such a distinction seems more appropriate to a philosopher or a semanticist than to a lawyer.

securities, and in such manner as will best serve the interest of my said children"). But cf. Duncklee v. Butler, 30 Miisc. 5S, 62 N. Y. Supp. 921 (Sup. Ct. 1899) (". . lieep the same invested in good, sound, dividend-paying securities. . . . He may also invest and reinvest the trust estate at discretion").

It is easy to understand why doctrinal confusion has arisen in courts which insist upon deciding cases on a conceptualistic basis. Where donors have used adjectives such as "good" or "safe" or "sound" to describe the type securities to be purchased without having added any language to indicate discretion, it is difficult to find any intent that the trustee should go beyond the legal list in investment. Miatter of Robbins, 135 Arisc 220, 237 N. Y. Supp. 409 (Surr. Ct. 1929) (". . safely and conservatively invested . . ."); Hale's Estate, 347 Pa. 177, 32 A.2d 20 (1943) (". . good sound securitics . . "); Berge's Estate, $30 \mathrm{~Pa}$ D. \& C. 549 (1937) (". . . some safe securities at interest . . ."); Plate's Estate, $30 \mathrm{~Pa}$. Dist. 902 (1921) (“. . good securities . .."). Contro: Fox Y. Harris, 141 MId. 495, 119 Atl. 256 (1922) (“. . . good, safe securities . ..").

Then when the court is confronted with an investment clause authorizing ". . . good sound securities as he may deem best," it has its choice of two perfectly logical but quite contradictory syllogisms. The first syllogism takes the incontrovertible major premise that ". . . legal securities as he may deem best" is a grant of discretion to choose only among legals. And granting the minor premise that "... good sound securitics" means "legal securities," the conclusion must follow as the night the days that ". . . good sound securities as he may deem best" is a grant of discretion to choose only among legals. The alternative syllogism starts with the equally incontrovertible major premise that ". . good sound securities without being confined to legals" is a grant of full power, and takes the minor premise illustrated in notes 37 and 38 supra that ". . . as he may deem best" means "... without being confined to legals." The conclusion then follows as another day another night that ". . good sound securities as he may deem best" is a grant of full power.

Confronted with this neat dilemma most courts have taken the conservative course and have adopted the first syllogism, confining the trustee to legals. That such a decision leaves the law of those jurisdictions confused and inconsistent is only another illustration of the invalidity of the conceptual method of reaching a judicial decision.

52. In re Leonard's Will, 118 Misc. 59S, 193 N. Y. Supp. 916 (Surr. Ct. 1922).

53. Cf. State National Bank of Tesarkana v. Murphy, 207 Arls 263,180 S. W.2d 118 (1944) (". . . such stocks, bonds, or other income-bearing securities, or other personal property as my said executor may deem safe and desirable"); City Banls Farmers Trust Co. v. Lewis, 122 Conn. 384, 189 Atl. 178 (1937) (". . . such other seeurities bzsides those recognized by law as they may consider safe ..."); Wilmington Trust Co. y. Worth, 19 Del. Ch. 314, 167 Atl. S48 (1933) ("... to invest... in, what in the discretion of the trustees are, good investments"); Mlatter of Kane, 25 N. Y. S.2d 988 (Surr. Ct. 1941) (". . . such securities as to it or them shall seem safe and proper"); In 
Once the full-power clause has been framed, it still may be desirable, especially in stringent jurisdictions, to add to it certain additional specific authorizations in order to give the trustee as free a rein as possible. As pointed out in the section on special powers, however, these extra clauses must make it clear that the grants are not exclusionary. ${ }^{44}$ For example, for the purpose of diversifying investments, in smaller trusts especially, it may be desirable to employ modern devices such as common trust funds and mortgage participations whose use in the absence of express authorization, might be challenged as improper delegation of powers by the trustee. Again, there are a number of subsidiary powers of pragmatic importance whose exercise might be contested in the absence of specific authorization. For example, the trustee may be empowered to employ an investment counsel and pay him from the estate. Without definite sanction, the trustee might be surcharged for such payments, since he is normally expected to select the investments himself. Such specific grants of authority however can be kept to a minimum if the general grant of power is sufficiently broad, and in any event, should themselves be drafted as models of studied simplicity.

\section{In General}

A good investment clause is not hard to draft. ${ }^{55}$ Most of the errors in draftsmanship arise when the donor and his scrivener have not thought through the effect which the investment clause will have. Once it has been decided how much power to grant, a simple statement ${ }^{\text {tb }}$ will usually suffice to extend that power clearly and unambiguously. ${ }^{57} \mathrm{~A}$ form book can be of

re Leavitt, 135 Misc. 387, 238 N. Y. Supp. 109 (Surr. Ct. 1929) (". . o other incomc-betring securities as they may select as being reasonably safe for the investment of trust funds").

54. See pp. 295-6 supra.

55. "It is not difficult to define broadly the investment powers of the trustees . . . in such words that no doubt can arise, and that the founder's lawful intent can be adopted by the trustee, and by the court." Morris, Problems in the Drafting and Administration of Trusts, 26 MARQ. L. REv. 57, 62 (1942).

56. Investment clauses present a perfect example of the type of draftsmanship complained of by Schaefler, Trust Agreements Are Stuffy, 86 Trusts \& EsTates 222 (1948): "Trust agreements are stuffy. They are needlessly involved, complicated and incomprchensible. They abound in circumlocutions and tautologies. . . . Must the meaning and purpose of the trust provisions be obfuscated by legal pidgin English? Can we not dispense with the 'whereas,' the 'witnesseth' and the parties of the innumerable part? Can we not translate the lengthy and involved clauses of the trust agreement, with their esoteric and cabalistic meanings, into the human and humane documents their creators intended them to be-literate, concise, understandable? Is it our idea that we 'must make the medicine taste bad' before the client will believe he is getting a really good legal job?" Schaefler suggests, at 223, the following investment clause: "You may retain any of the securities on the attached list without diversifying them, or you may sell them and invest the proceeds in any stocks, bonds, or other securities, even if they are not specified as being legal for trust investments."

57. For a full power, for example, an English writer suggests: "My trustees may in- 
assistance provided that the lawyer drafting the instrument understands the effect of the language used, and does not blindly copy suggested clauses. ${ }^{23}$ The advice often given to use language which has been frequently construed by the courts is likely to be dangerous; probably the best investment clauses are drafted with such clarity and so simply that the courts have had no occasion to interpret their meaning.

\section{Conclusion}

A system which wisely leaves to each man the right to dispose of his goods as he will implies a donor making a considered, informed decision as to the investment power which he wishes to give his trustee. It implies an ability to translate the wishes of the donors into clear and unambiguous language

vest the trust fund in any form of property they think fit as if they were a single absolute owner thereof." Inz'estment Clauses, 90 SoL. J. 413 (1946). In the course of a survey made by an Editor of the YALE LAw JOURNAL of the investment clauses of more than 4500 trusts administered by an outstanding trust company, only one trust was encountered in which the investment clause had the same refreshing simplicity as that suggested by the English scholar. That one clause merely said: "To purchase any kind of property whatsoever." While this undoubtedly gives a full power in the jurisdiction in which the trust is located, a specific exemption of the requirement of legals is advisable for most trusts.

"MIy trustee may make investments other than those legal for fiduciaries," or "to invest, reinvest, and keep invested, without being confined to legal investments," or "to invest without limitation to so-called 'legal investments' under the law of any State"-language of this sort, with its countless variants, is seen in many trusts. Where sudh language is present the trustee can invest according to his best judgment without having to get expensive opinions of counsel on the interpretation of the investment clause and without worrying about ever being surcharged for buying non-legals.

The clause suggested by Holden, Estates Under Wills ard Trust Agreene:sts 37 (1928) seems satisfactory, even if somewhat more expansive than necessary: "The Trustee shall not, in making investments, be to any extent restricted to those by statutory law made available for trust investment, and may make any investment in stocks, bonds, mortgages or property which a prudent business man, exercising ordinary care, might make of his oun funds." The addition which Holden recommends be made to that clause would add considerably to the administrative difficulty, and is quite undesirable: "Provided however that unless an investment is one which is qualified as an investment of trust funds, no investment shall be made by the Trustee in securities, whether bonds or stocks, which are subject to any existing substantial amount of first liens or charges, superior in lien to such securities." Ibid. The problem of determining what is a "substantial amount" of prior liens would cause much anguish to the trustee, and it is even possible that a hostile court could construe the proviso as forbidding the purchase of any common stocks whatsoever in companies with preferred stock or bonds outstanding. The donor should have sufficient confidence in the ability and good judgment of his trustee to let the trustee determine whether senior obligations are such as to make an investment unwise.

58. The following investment clause, drafted by a very competent metropolitan law firm, is an outstanding example of "formbookitis"-the dread disease of using a form books without thinking about what is being said: "In trust upon the decease of the last survivor of my sons to invest in other than what are known as legal investments provided that this power shall not be exercisable in such way as to permit the purchase of shares of stock of corporations or investments in other than bonds of corporations or individuals secured by mortgages or collateral trust agreements or provisions of like character." 
in the trust instrument. And it implies courts and trustees who will interpret this language in such a way as to carry out the spirit of the testator's directions, ${ }^{69}$ rather than base their construction of the instrument on hoary precedents, outmoded declarations of legislative policy, ${ }^{60}$ or quibblesome semantics. There is no reason why these implications must so often represent conditions contrary to fact.

59. An extreme example of a court frustrating the intent of the donor is $I n$ re Safe Deposit Bank of Pottsville, $19 \mathrm{~Pa}$. D. \& C. 695 (1933). In that case the court interpreted some fairly ambiguous language as giving only a legal power despite testimony of the settlor himself that by the language he meant to give his trustee a full power. The sound rule that the investment clause may not be modified by parol evidence, 3 BocErT $\$ 681$, does not seem necessarily to conflict with letting the settlor himself be of assistance in determining his own intent.

60. One writer actually finds it desirable to resolve ambiguities in investment clauscs by use of the anachronistic policy of conservatism contained in the legal lists. Exclusion and Application of Statutory Investment Norms by the Instrument Creating the Trust, 19 IowA L. REv. 441 (1934). That article argues that courts are too quick to find a grant of discretion, and should confine trustees to the legal list unless the testator specifically states that the legal limits are not to apply. The explanation for the position taken by that article probably is that it was written at the height of the depression when many trusts were experiencing large losses on non-legal securities. 